\title{
Potential Use of Rum Distillery Slops as Animal Feed Supplement. IV. Fodder Yeast Growth in Slops ${ }^{1}$
}

\author{
Mario Ramírez and Isabel M. González ${ }^{2}$ \\ ABSTRACT
}

\begin{abstract}
Experiments on fodder yeast growth in rum distillery slops showed best results in slops with added nutrients, $0.15 \% \mathrm{~N}$ as $\left(\mathrm{NH}_{4}\right)_{2} \mathrm{SO}_{4}$ and $0.10 \% \mathrm{P}$ as $\mathrm{KH}_{2} \mathrm{PO}_{4}$. More than $60 \%$ BOD reduction was obtained with a 24-h growth. Average yeast yield obtained was $10 \mathrm{~g} / \mathrm{L}$ of dried yeast with a $32-40 \%$ protein content. The 1:1 slops-water dilution gave the best results.
\end{abstract}

\section{INTRODUCTION}

The revenue from rum sales in Puerto Rico amounts to more than 160 million dollars yearly. This income is presently threatened by the industry's inability to dispose properly of its effluents. A total of 300 million gallons of slops, with a biological oxygen demand (BOD) of 30,000 to $40,000 \mathrm{p} / \mathrm{m}$ is dumped yearly on land and into coastal waters. The

TABLE 1.-Composition of molasses and slops ${ }^{1}$

\begin{tabular}{lcc}
\hline \multicolumn{1}{c}{$\%$} & Molasses & Slops \\
\hline $\mathrm{H}_{2} \mathrm{O}$ & 25.4 & 90.0 \\
$\mathrm{~N}$ & 1.1 & 0.2 \\
$\mathrm{P}$ & 0.1 & 0.003 \\
$\mathrm{~K}$ & 2.7 & 0.6 \\
$\mathrm{Ca}$ & 1.0 & 0.2 \\
$\mathrm{Mg}$ & 0.5 & 0.1 \\
$\mathrm{Na}$ & 0.2 & 0.02 \\
$\mathrm{SO}$ & 2.4 & 0.3 \\
$\mathrm{Cl}$ & 1.1 & 0.2 \\
Sucrose & 32.1 & 4.0 \\
Reducing Sugar & 30.0 & 0.6 \\
Caramel & - & 2.9 \\
\hline
\end{tabular}

' Pérez Escolar, R., Reclamation of a saline-soil by use of molasses and distillery slops, J. Agri. Univ. P.R. 50 (3): 209-17, 1966.

Environmental Protection Agency (EPA) has ruled that this industry must find a solution to the problem before 1983.

Realizing the magnitude of this problem and the catastrophic effect it could have upon the economy of Puerto Rico, researchers initiated several

'Manuscript submitted to Editorial Board January 29, 1979.

${ }^{2}$ Assistant Chemist and Associate Chemist, respectively, Rum Pilot Plant, Agricultural Experiment Station, College of Agricultural Sciences, Mayagüez Campus, University of Puerto Rico, Río Piedras, P.R. 
years ago a development program in this area at the Rum Pilot Plant. One of the research areas included the fermentation of slops with fodder yeasts to enrich the protein content for their potential use as an animal feed supplement.

The nutritive value of slops in terms of nitrogen level is low (table 1), especially if they are to contribute significantly to the animal diet. Aguinaldo (1) stated that in the propagation of yeast the necessary requirements for favorable growth are low concentration of sugar, low $\mathrm{pH}$, high organic nitrogen content, adequate supply of air, and presence of growth-promoting substances. Rum slops fill the majority of these requirements. These microorganisms are important sources of food because their cell matter is rich mostly in B-group vitamins and in protein that contains essential amino acids.

The following tabulation shows the Chang and Yang approximate analysis of dried Torula yeast (4).

General composition

Moisture

Crude protein

Crude fat

Crude fiber

Ash

$\mathrm{N}$ free extract

Minerals

$\mathrm{CaO}$

$\mathrm{MgO}$

$\mathrm{P}_{2} \mathrm{O}_{5}$

$\mathrm{Fe}_{2} \mathrm{O}_{2}$

$\mathrm{K}_{2} \mathrm{O}$

$\mathrm{Na}_{2} \mathrm{O}$

Zinc

Copper

Amino acids

Alanine

Arginine

Aspartic acid

Cystine

Glutamic acid

Glycine

Histidine

Isoleucine
$\%$

7.73

45.17

2.79

1.82

7.68

34.81 .

Ash \%

3.28

4.21

39.17

0.74

37.56

14.49

$2 \mathrm{mg} / 100 \mathrm{~g}$

$7.8 \mathrm{mg} / 100 \mathrm{~g}$

Protein \%

6.01

5.19

8.68

0.31

16.09

4.25

1.61

4.54 
Leucine $\quad 6.43$

Lysine $\quad 6.45$

Methionine $\quad 1.28$

Phenylalanine $\quad 4.18$

Proline $\quad 3.04$

Serine $\quad 4.24$

Threonine $\quad 4.54$

Typtophan 1.11

Tyrosine $\quad 3.53$

Valine $\quad 5.33$

Vitamins

$m g / 100 g$

Thiamine $\quad 0.9$

Riboflavin $\quad 3.5$

Niacin $\quad 35.0$

Pantothenic acid $\quad 5.64$

Biotin $\quad 0.59$

Choline $\quad 114.8$

Vitamin $\mathrm{B}_{6} \quad 4.8$

They mentioned three advantages in the production of yeast: 1) a large quantity of protein can be produced in a limited area; 2) the same quantity of biomass is produced in less time with yeasts than with plants or livestock; 3) $90 \%$ of the nutrients are absorbed by the yeast in the fermentation tank, whereas when fertilizers are applied to land part of them are leached off through the soil.

Protein production for animal feed has been discussed by López Hernández (7). He suggested that a product rich in protein can be obtained from cane molasses slops fermented with Candida utilis and Torulopsis utilis. He stated that $15-20 \mathrm{~kg}$ of dried yeast can be obtained per $\mathrm{m}^{3}$ of slops. Seven thousand tons of dried yeast per year would produce 3,000 tons of protein.

Skripnik (15) produced feed concentrates from refuse of the alcohol industry containing protein, antibiotics and vitamins. He found that fermentation of slops with Candida tropicalis gave a product that contained biomycin and vitamin $\mathrm{B}_{12}$, suitable for feed. Zabrodskii (17), studying the possibility of obtaining higher yields of nutrient yeast from molasses residues, found that cultivating it in a 2 -step process using certain strains of Saccharomyces increased the yield of biomass. A thoroughly fermented mash and a spent wash high in inorganic matter, but low in salinity, gave higher yeast yields. He also studied (18) the biosynthesis of fat by Rhodotorula glacilis yeast cultured in molasses vinasses, obtaining yeast biomass with $22-25 \%$ fat from $1 \mathrm{~kg}$ of vinasses.

Brahmer (3) presented the technique and economics of fodder yeast 
production from Torula utilis and the possibility of its growing in pentose-rich distillery residues. Boruff (2) recovered feed products from stillage by re-fermentation.

Rachlevicius(13) manufactured dry fodder yeast from distillery residues, and set the following conditions for the fermentation: $34-36^{\circ} \mathrm{C}, \mathrm{pH}$ 5 to 5.5 , and foaming induced by sparging with filtered air. Conditions for cultivating fodder yeasts were presented by Semenets (14). He used $\mathrm{H}_{3} \mathrm{PO}_{4}, \mathrm{H}_{2} \mathrm{PO}_{4}, \mathrm{H}_{2} \mathrm{SO}_{4},\left(\mathrm{NH}_{4}\right)_{2} \mathrm{SO}_{4}$ and $\mathrm{H}_{2} \mathrm{O}$ for dilution during the cultivation of Candida tropicalis, strains SK-4 and D-3. Best yields were obtained at $30-32^{\circ} \mathrm{C}$ and at $\mathrm{pH} 4.7$ to 5.2 with strain D-3.

Yeast cultivation in molasses slops supplemented with molasses was studied by Malanowska (8). She obtained yields of $18-20 \%$ yeast with respect to the total solids of the slops by cultivation of fodder yeast Torulopsis utilis in distillery molasses slops supplemented with $10 \%$ beet molasses at $33-35^{\circ} \mathrm{C}$ and $\mathrm{pH} 4.5$ to 5.0 .

Experiments conducted by Matsuo et al. (9) with various yeast strains in modified slops media showed that Candida utilis, C. arborea and C. tropicalis were superior strains for yeast production in slops supplemented with $3 \%\left(\mathrm{NH}_{4}\right)_{2} \mathrm{HPO}_{4}$ and $0.03 \% \mathrm{MgSO}_{4} \cdot 7 \mathrm{H}_{2} \mathrm{O}$. He also found (10) that the yeast $C$. utilis cultured in distillery slops contained more than $50 \%$ crude protein, and reduced the BOD of the medium by $50 \%$. Karaki (5) found that the addition of $0.2-0.7 \%$ sucrose to slops to be fermented with Candida utilis increased the yield of yeast to about $0.15 \%$ and that it had no effect on the fermentation process. Clarification of molasses showed no appreciable effect on the yield and quality of the yeast. Kozlowska (6) studied the utilization of some components from vinasse and molasses during yeast production, and found that Torulopsis utilis grown in vinasses containing $10 \%$ molasses utilized more reducing substances and organic non-carbohydrate substances than that grown in vinasse or molasses alone.

If rum distillery slops prove to be valuable for the growth of fodder yeast, Puerto Rico will have a way of increasing the production of edible protein. In this case, rum slops instead of being an undesirable waste would become a valuable agricultural and industrial by-product resource. This paper reports work initiated in Puerto Rico.

\section{MATERIALS AND METHODS}

Fodder yeast growth experiments were performed both on laboratory and small-plant scales. Laboratory scale experiments were carried out in a New Brunswick Scientific Co., Magnaferm Fermenter Model MA-100. ${ }^{3}$

\footnotetext{
${ }^{3}$ Trade names in this publication are used only to provide specific information. Mention of a trade name does not constitute a warranty of equipment or materials by the Agricultural Experiment Station of the University of Puerto Rico, nor is this mention a statement of preference over other equipment or materials.
} 
This fermenter consists of a 14-liter glass vessel equipped with a magnetically-driven triple propeller stirrer and a mechanical foam breaker. Temperature and $\mathrm{pH}$ were automatically controlled and continuously recorded during the experiments. The temperature of the fermenter was kept betwen $28-30^{\circ} \mathrm{C}$ and aeration was controlled as specified in tables 2 to 4 . Small-plant scale experiments were carried out with continuous aeration and agitation in a pre-seed and a seed tank, 25- and 250-gal capacity, respectively. Sulphonated castor oil plus internal pressure was used to minimize foaming.

Yeast strain PPR-291, Candida utilis, obtained from the Northern Regional Research Laboratories was used as growth organism in all

TABLE 2.-Fodder yeast growth in slops

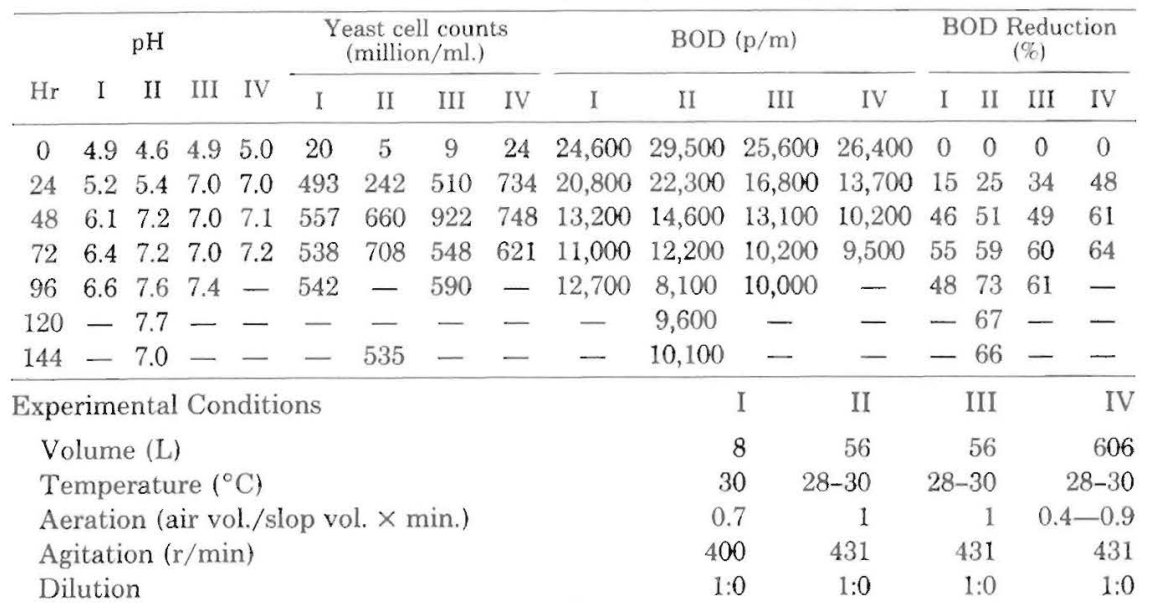

experiments. Slops used in the experiments were obtained from the Bacardí distillery in Cataño, Puerto Rico.

The study considered three aspects: 1) yeast growth in sterile raw slops; 2) effect of slops dilution on yeast growth; and 3) addition of nutrients and their effect on yeast growth. For the preparation of inocula, a purified yeast culture was transferred from agar slants of a synthetic medium (12) to $35 \mathrm{ml}$ liquid synthetic media. Samples were agitated continuously at room temperature in a mechanical shaker; and after 48 hours, each one was transferred to $250 \mathrm{ml}$ sterile distillery slops in $500 \mathrm{ml}$ Erlenmeyer flasks and again shaken continuously for 24 hours. A seed of $5 \%$ fermentor volume was used as inoculum.

For dilution experiments, slops were diluted with tap water. When necessary, nutrient salts were added: $\left(\mathrm{NH}_{4}\right)_{2} \mathrm{SO}_{4}$ for $\mathrm{N}$ and $\mathrm{KH}_{2} \mathrm{PO}_{4}$ for $\mathrm{P}$. 
TABLE 3.-Fodder yeast growth in diluted slops

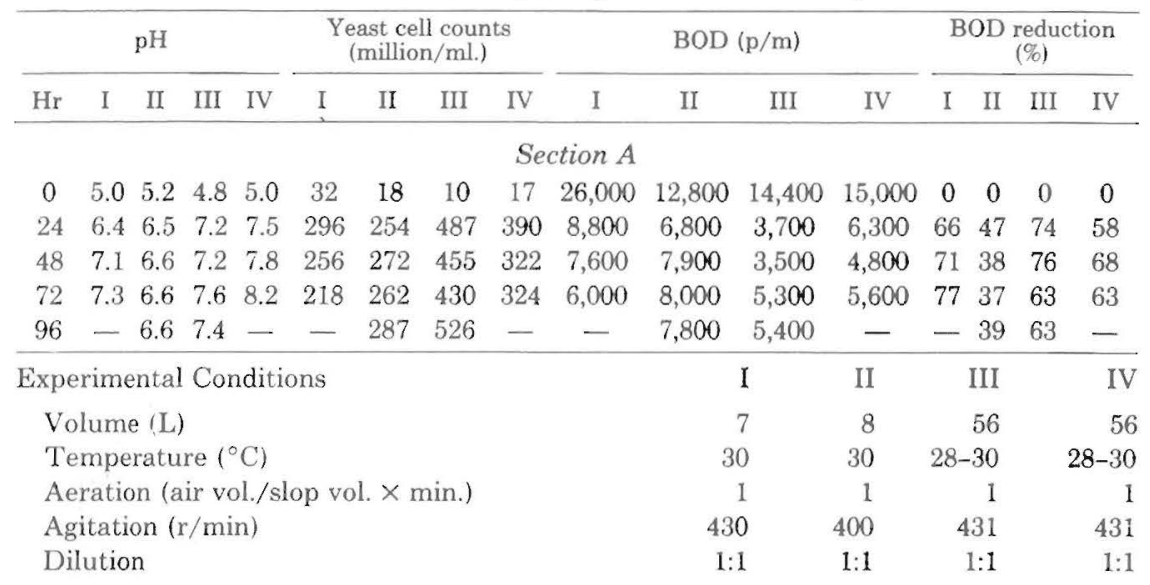

Section B

\begin{tabular}{rllllllllllllllll}
\hline $\mathrm{Hr}$ & $\mathrm{V}$ & VI & VII & VII & V & VI & VII & VII & V & VI & VII & VIII & V VI & VII & VIII \\
\hline 0 & 5.1 & 5.3 & 5.0 & 5.1 & 20 & 16 & 19 & 24 & 10,400 & 8,500 & 17,800 & 18,900 & 0 & 0 & 0 & 0 \\
24 & 6.5 & 6.6 & 7.2 & 6.8 & 189 & 206 & 550 & 548 & 6,000 & 4,500 & 9,300 & 9,100 & 42 & 47 & 48 & 52 \\
48 & 7.1 & 6.8 & 7.2 & 7.0 & 275 & 163 & 512 & 520 & 5,700 & 4,900 & 9,400 & 9,700 & 45 & 42 & 47 & 49 \\
72 & 7.2 & 6.8 & 7.1 & 7.0 & 199 & 167 & 467 & 556 & 3,700 & 4,900 & 9,600 & 11,500 & 64 & 42 & 46 & 39 \\
96 & - & 6.9 & - & - & - & 165 & - & - & - & 4,700 & - & - & - & 45 & - & - \\
\hline
\end{tabular}

The laboratory scale experiments showing best data were later conducted in small-plant scale.

$\mathrm{BOD}$, yeast cell count, and $\mathrm{pH}$ were determined in all experiments. Dry weight, ${ }^{\circ} \mathrm{Brix}, \mathrm{K}$ content, total sugars and percentage protein of the yeast were measured in selected experiments. BOD analyses were performed by two different methods (16). Since no significant difference was found between the two, the electrometric method was selected for convenience. Yeast was recovered by centrifuging $10 \mathrm{ml}$ sample of the liquid and drying the residue at $105^{\circ} \mathrm{C}$. Protein was determined by the Kjeldahl method and $\mathrm{K}$ by atomic absorption spectrophotometry method. Other analyses were performed following official methods $(11,12)$. 
TABLE 4.-Fodder yeast growth in slops, nutrients added

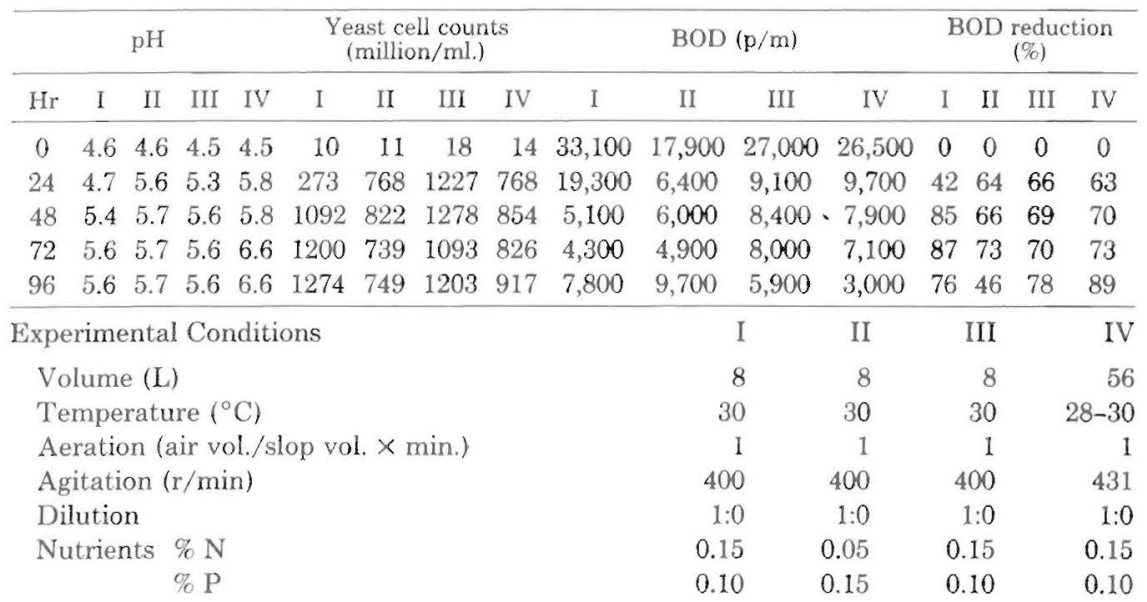

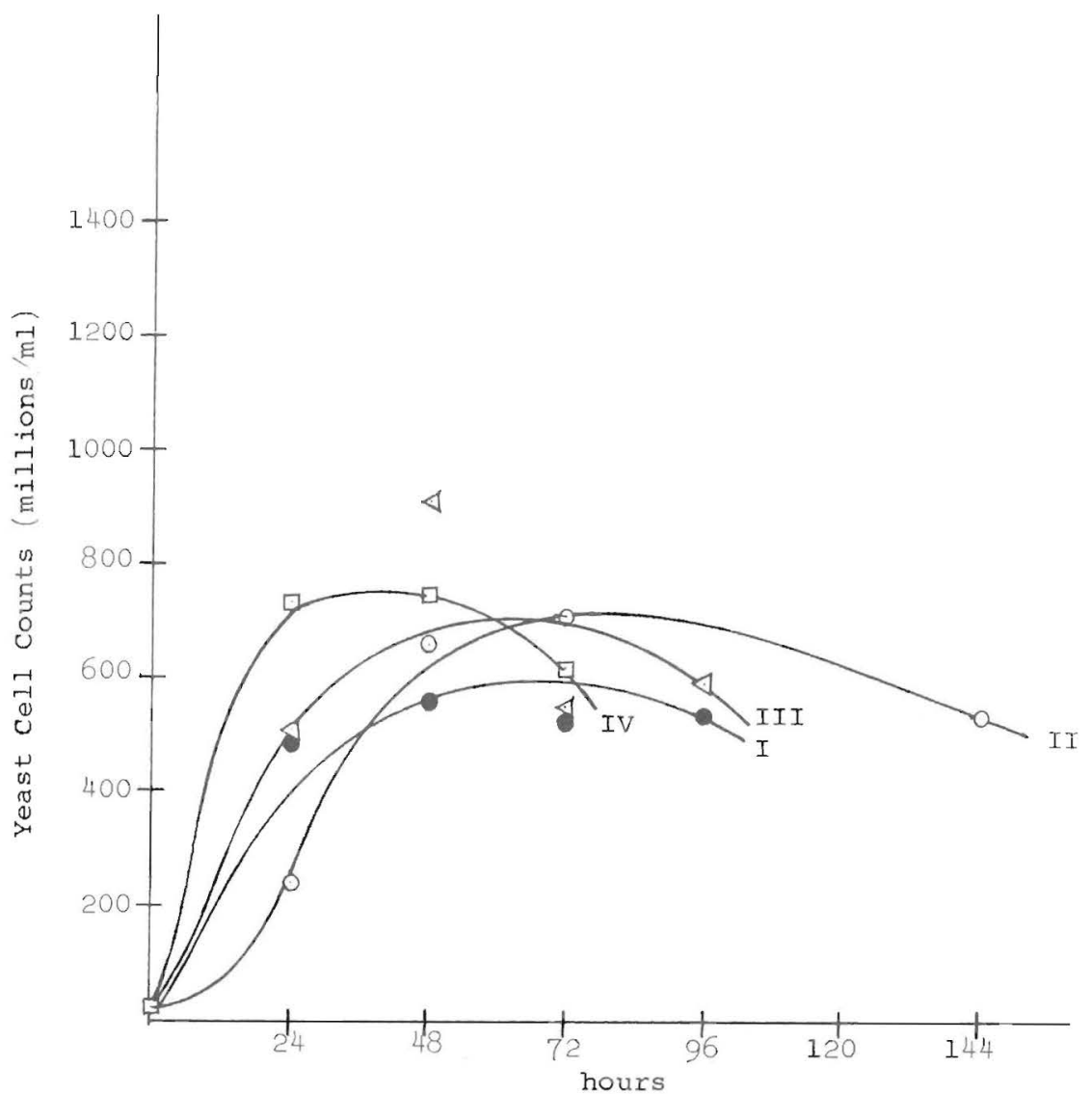

FIG. 1.-Yeast cell counts in slops. 


\section{RESULTS AND DISCUSSION}

Table 2 and figures 1 and 2 show the results on yeast growth in raw slops. Fodder yeast increased $\mathrm{pH}$ from acidic to neutrality levels during the first 48-hour growth period. High yeast yields in terms of total cell counts were obtained during the first 48 hours in sterile raw slops: an average of $10 \mathrm{~g}$ dried yeast of $32-40 \%$ protein content per liter of slops. BOD reductions of $55-60 \%$ were observed in 72 hours. Reductions in BOD were found directly proportional to yeast cell counts.

Table 3 and figures $3-6$ summarize the data of the dilution experiments with fodder yeast. As in raw slops, the $\mathrm{pH}$ turned from acid to about

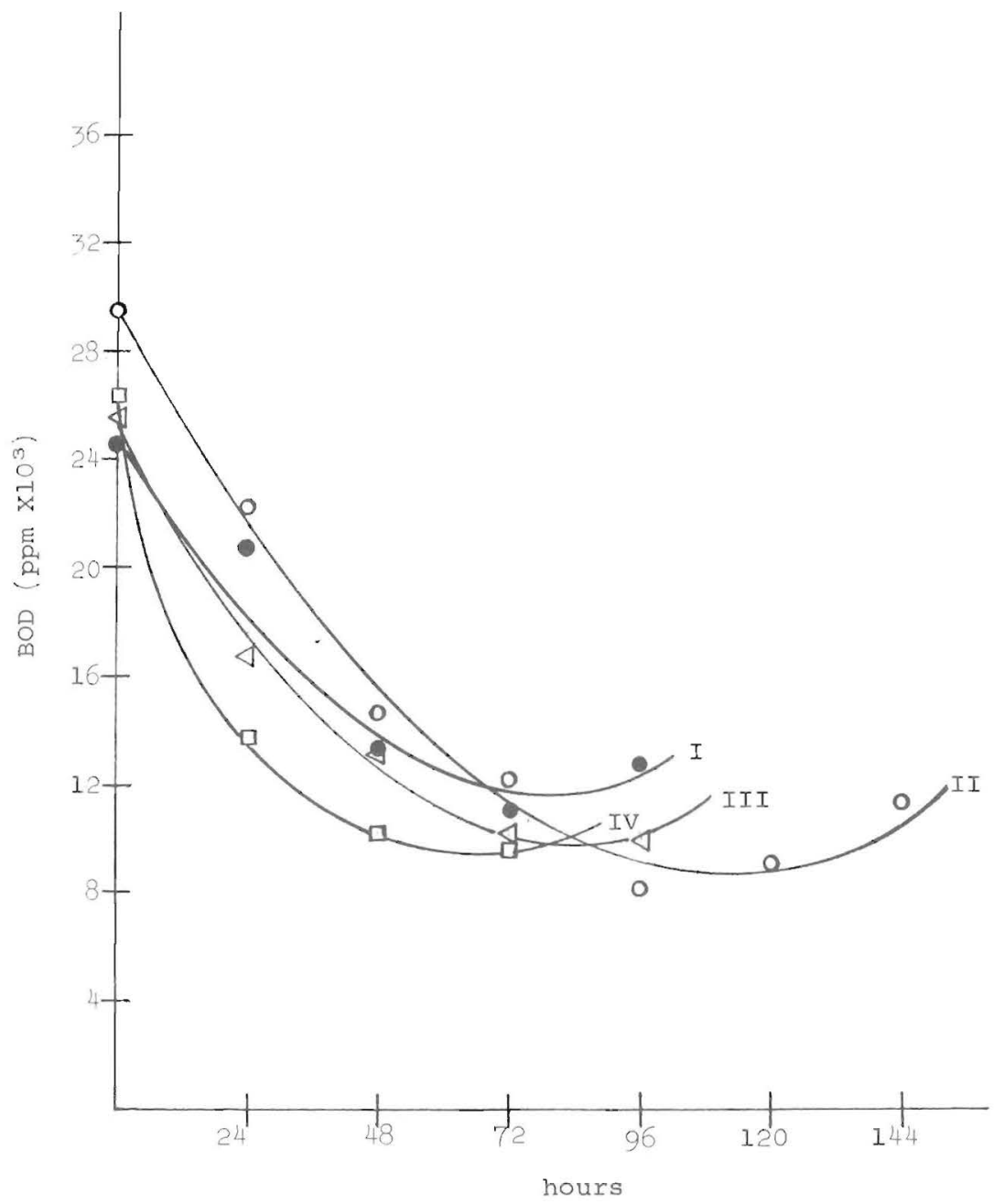

FIG. 2.-Effect of yeast growth on BOD of slops. 


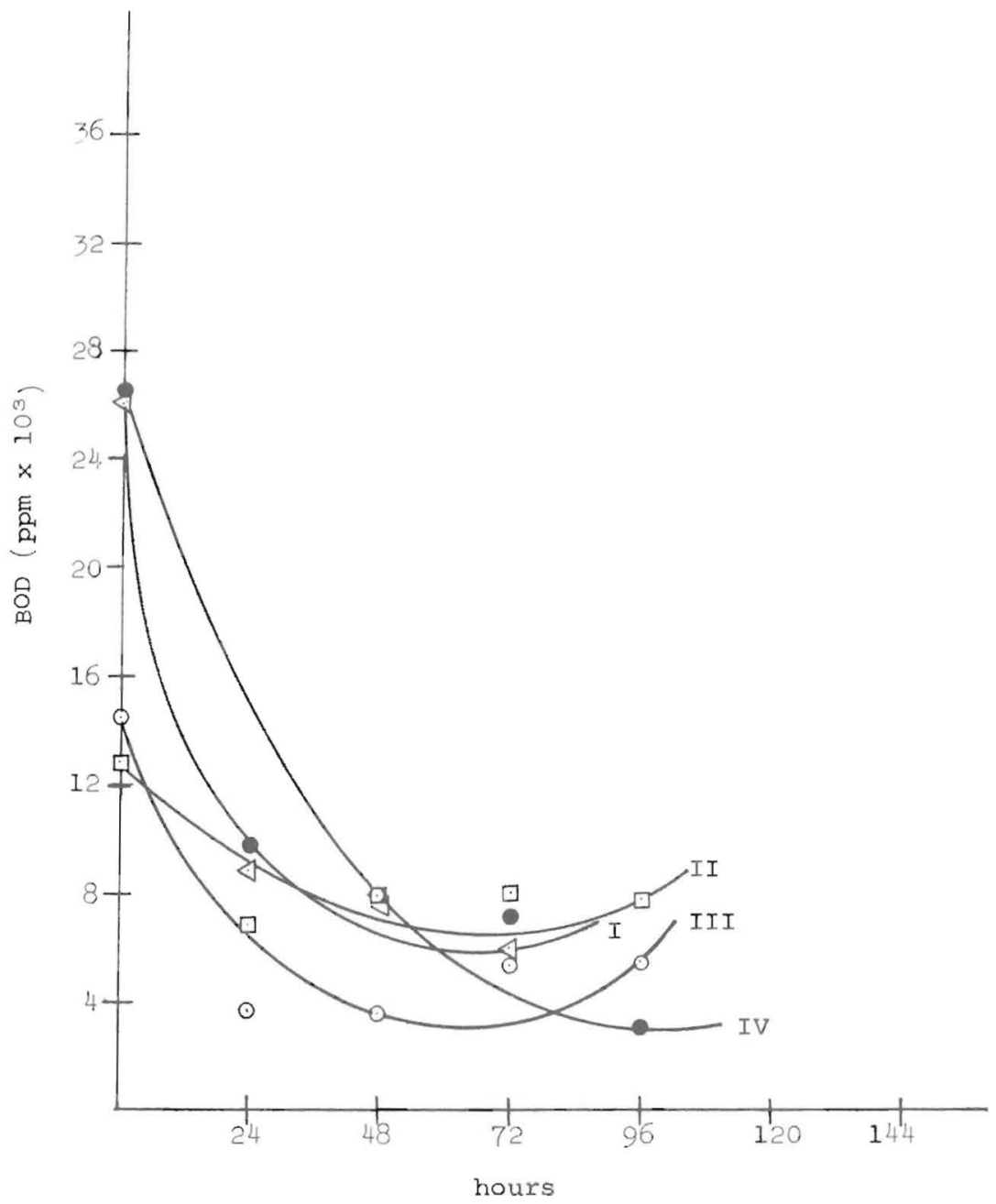

FiG. 3.-Effect of yeast growth on BOD of diluted slops (1:1) 


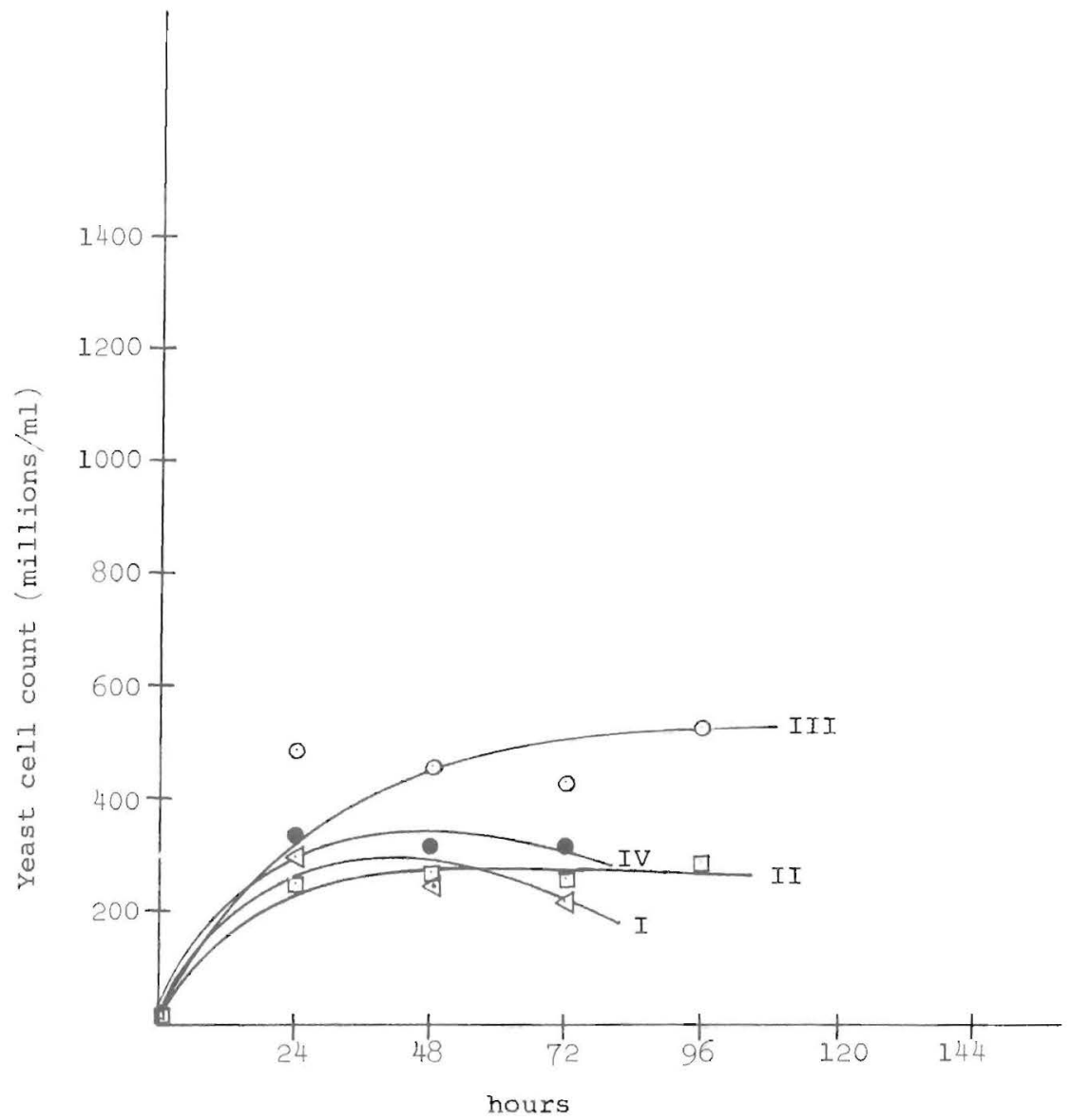

FIG. 4,-Yeast cell counts in diluted slops. 


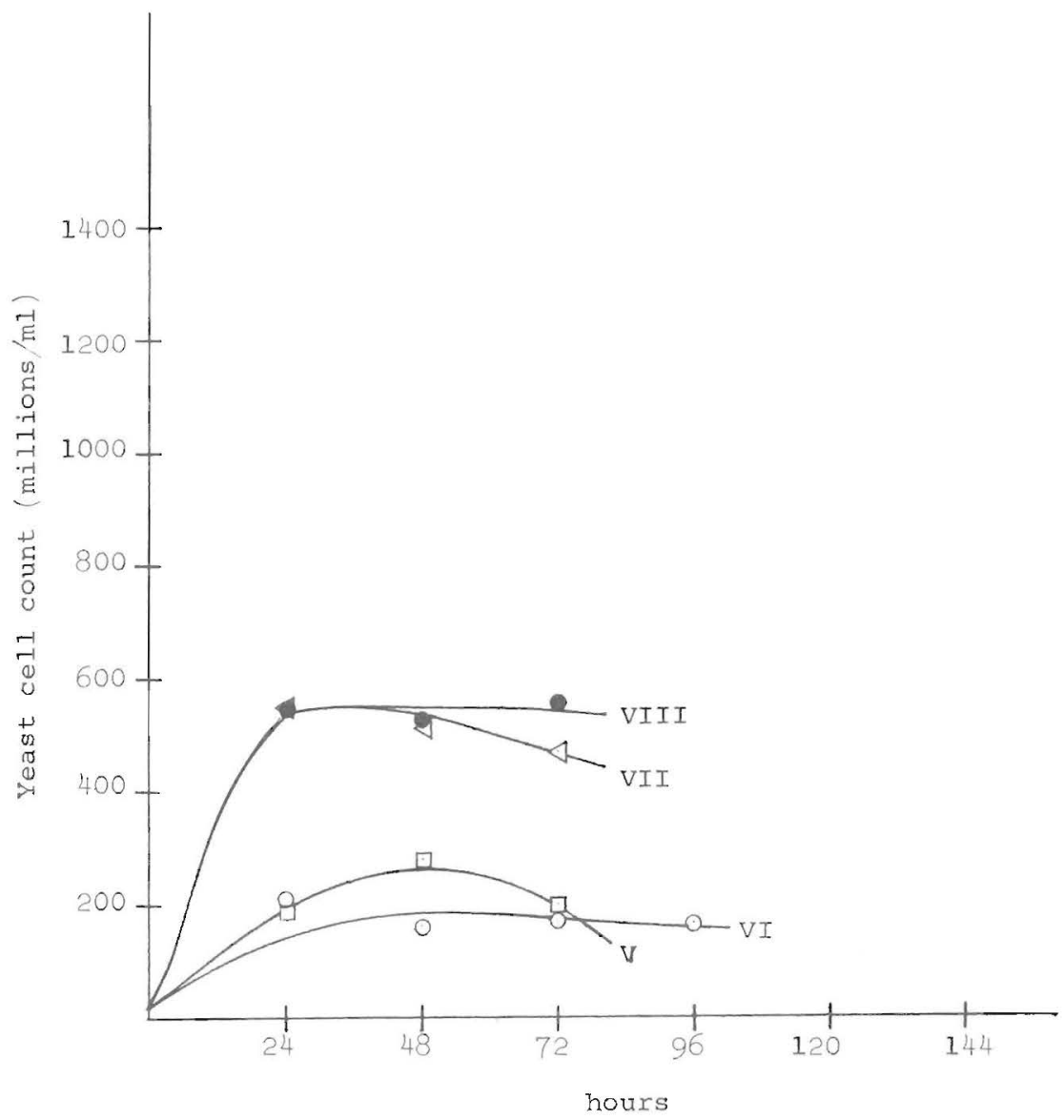

FIG. 5.-Yeast cell counts in diluted slops. 


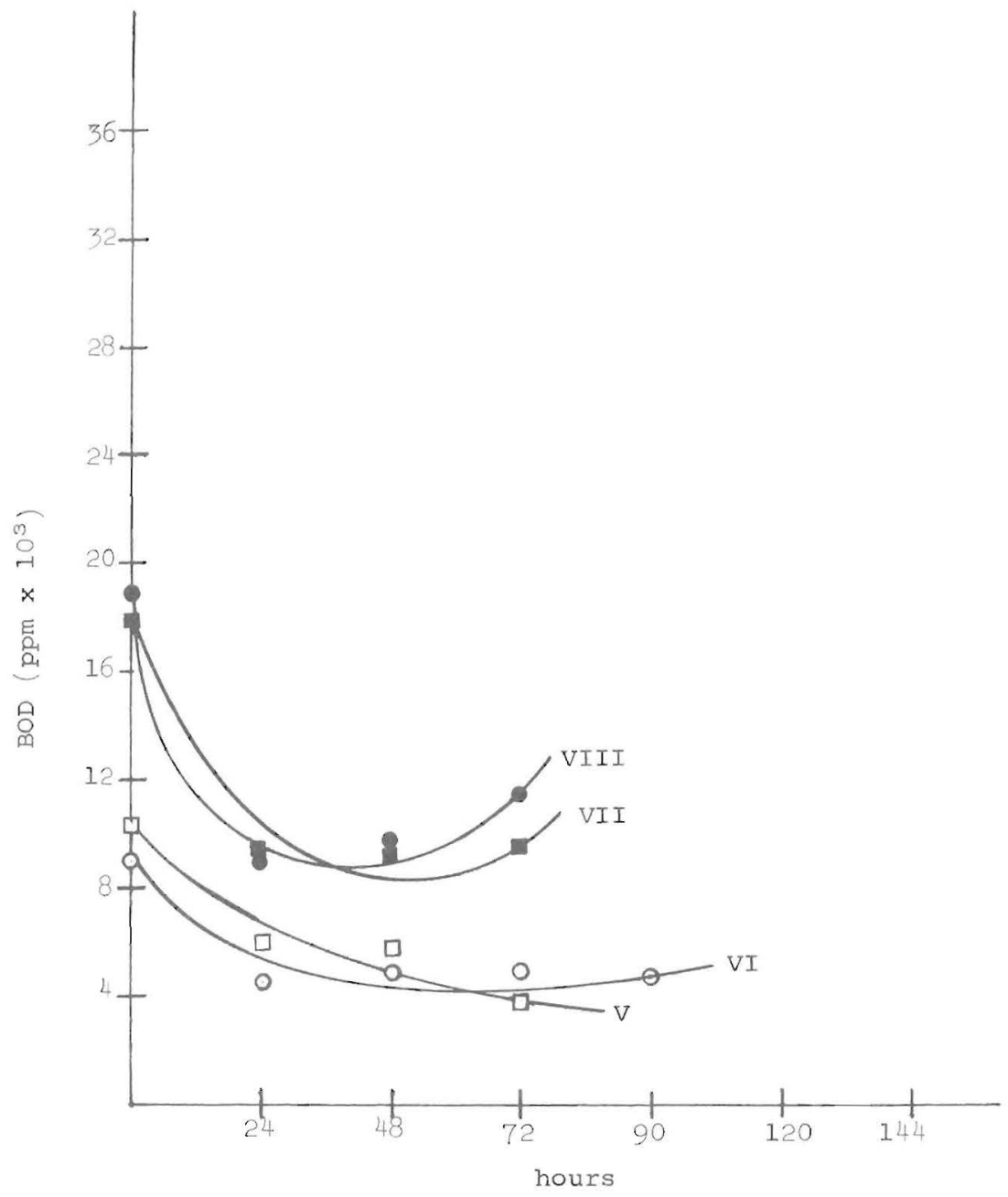

FIG. 6.-Effect of yeast growth on BOD of diluted slops. 
neutral in a short time. Maximum yeast cell counts were attained at 2448 hours with $5 \mathrm{~g} / \mathrm{L}$ yeast yield for a 1:1 dilution. Best results in terms of $\mathrm{BOD}$ reductions were obtained with 1:1 slops-water dilution.

Table 4 and figures 7 and 8 show the effect of added nutrients on yeast growth in slops. A lower increase in $\mathrm{pH}$ was observed during yeast growth experiments with added nutrients as a consequence of higher utilization of $\mathrm{NH}_{4}{ }^{+}$ions from the media. Best results were obtained with $0.15 \% \mathrm{~N}$ and $0.10 \%$ P. After 24 hours' growth, more than $60 \%$ BOD reduction was observed. High yeast cell counts were obtained at 48-72 hours.

It can be concluded that in all the experiments the best results were obtained in raw slops with added nutrients. Total yeast cell counts at 48

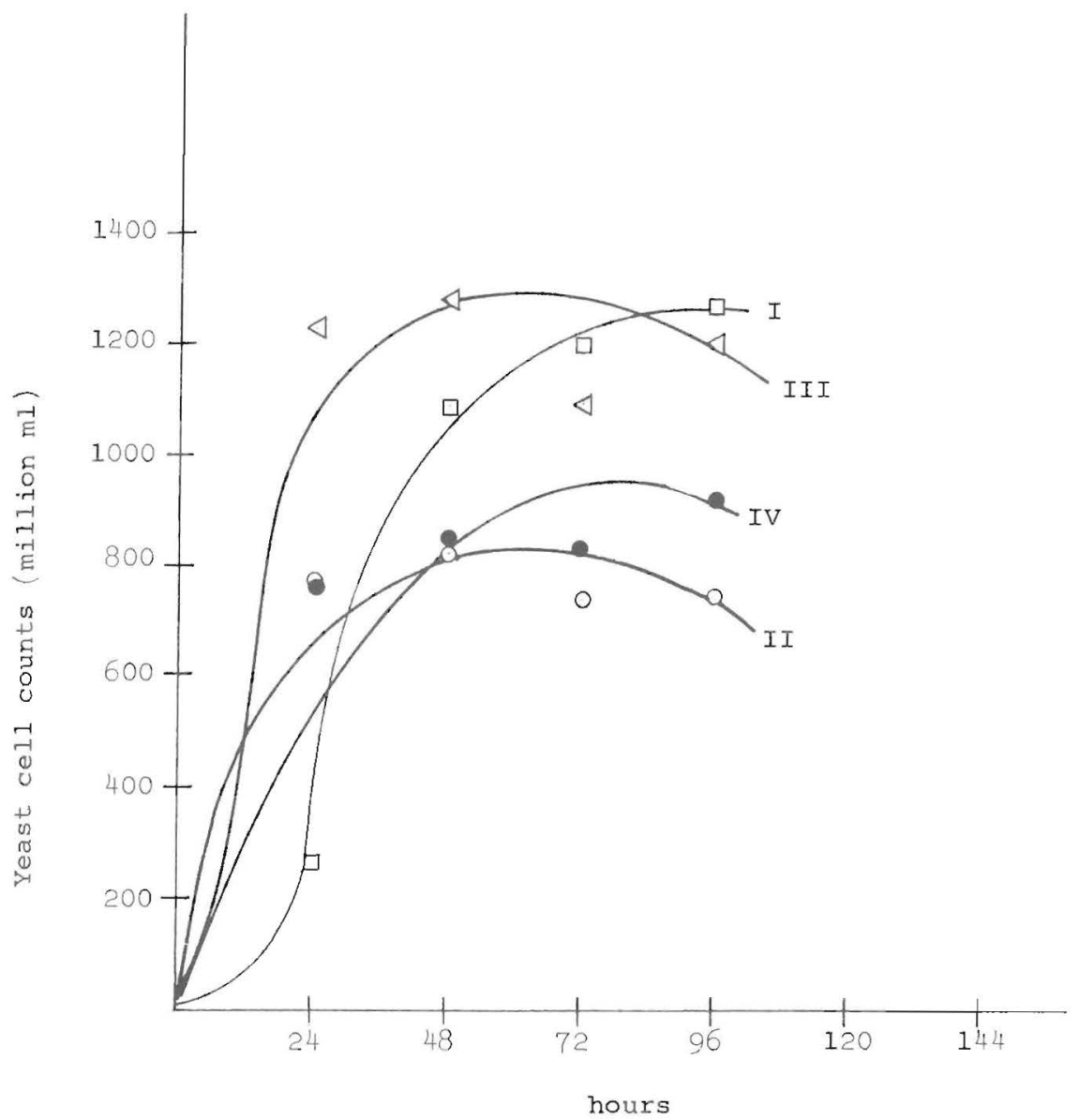

Fig. 7.-Yeast cell counts in slops, nutrients added. 


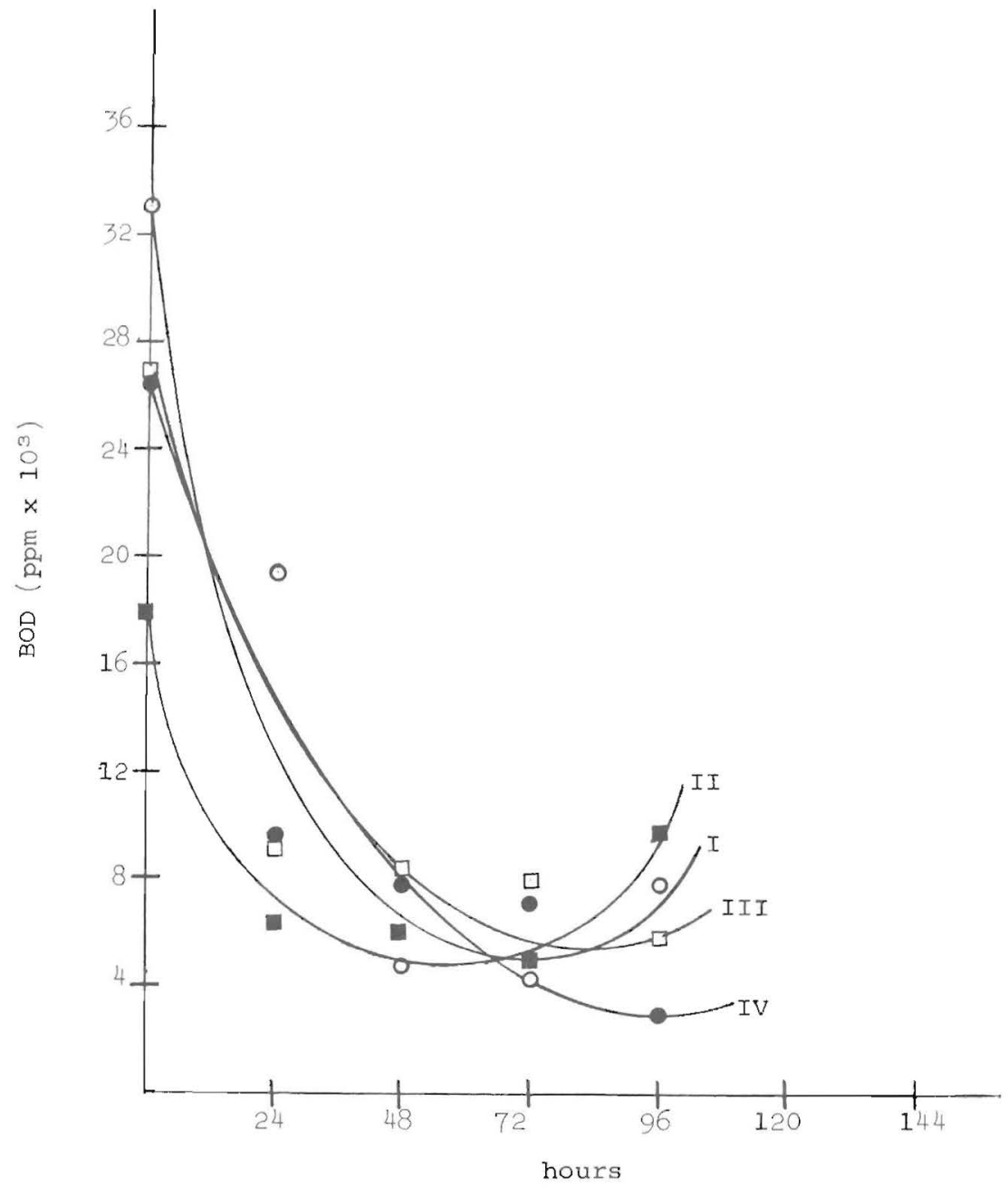

FIG. 8.-Effect of yeast growth on BOD of slops, nutrients added.

hours were higher in slops with nutrients than in raw or diluted slops with an average BOD reduction of $72 \%$.

\section{RESUMEN}

Experimentos sobre el crecimiento de levadura forrajera en mostos mostraron un aumento en el $\mathrm{pH}$ de los mismos durante las primeras 48 horas de crecimiento. Se alcanzaron rendimientos altos de levadura, obteniendo 10 gramos de levadura seca por litro de mostos, con un contenido en proteína de $32-40 \%$. Las reducciones de BOD más altas 
se obtuvieron a las 72 horas, 55-64\%. Los conteos de levadura se pudieron relacionar directamente con las reducciones en BOD; a más elevado el conteo, mayor la reducción de BOD obtenida. Se estudió además el efecto de la dilución, obteniendo conteos máximos a las 2448 horas y produciendo $5 \mathrm{~g} / \mathrm{I}$ de levadura seca en la dilución 1:1. Entre las diluciones estudiadas las reducciones de BOD más altas se obtuvieron con esta dilución. El efecto de sales nutritivas se exploró obteniendo los mejores resultados usando $0.15 \% \mathrm{~N}$ y $0.10 \% \mathrm{P}$. Un promedio de $72 \%$ en la reducción del BOD se obtuvo a las 48 horas de crecimiento. De todas las variables estudiadas, los mejores resultados se obtuvieron en mostos con nutrimentos, ya que la reducción del BOD se obtuvo en un tiempo de retención más corto.

\section{LITERATURE CITED}

1. Aguinaldo, J. T., 1975. Utilization of the distillery slops for continuous propagation of Torula yeast, Sugar News 354-6, September.

2. Boruff, C. S., Stone L., Bauernfeind, J. C., and Garey, J. C., Recovery of feed products from stillage by refermentation (to Hiram Walker \& Sons, Inc.), U.S. 2, 595, 827, May 6, 1952; C.A. 47, 6090h, 1953.

3. Brahmer, H., Production of fodder yeast, Kgl. Lantbruksakad. Tid. 81, 301-16, 1942; C.A. 39, 2161, 1945.

4. Chang, C. T. and Yang, W. L., 1973 (Yeast \& Feed Factory, T.S.C.), Torula yeast production from blackstrap molasses, Taiwan Sugar 20(5), 193-9, September-October.

5. Karaki, I., Nishioka, S., and Konishi, K., Yeast production from alcohol distillation slops of cane molasses, II, Hakko Kyokaishi 26(4), 173-86, 1968 (Japan); C.A. 69, $34675 p, 1968$.

6. Kozlowska, E. and Malanowska, J., Utilization of some components from vinasse and molasses and molasses and vinasse containing worts during yeast production, Przemysl Ferment. 8(11), 388-9, 1965 (Pol); C.A. 64, 11823a, 1966.

7. López Hernández, J. and Paz, H. A., 1972. Potential of Tucumán province in the protein production, La Industrial Azucarera 113-6. Universidad de Tucumán, Facultad de Agronomía y Zootecnia, Misceláneas No. 48, Tucumán, Argentina.

8. Malanowska, J., Skiba, M., Lebendzinski, S., and Wojcieszak, P. (Inst. Przem. Ferment., Warsaw, Poland), Yeast cultivation on the molasses slops, supplemented with molasses, Pr. Inst. Lab. Badaw, Przem. Spozyw. 17(3). 27-48, 1967 (Pol.); C.A. 68, 10387t, 1968.

9. Matsuo, T., Ishikawa, F., Yamanaka, M., and Konishi, K., Yeast production from alcohol distillation slops of cane molasses I, Hakko Kyokaishi 23(7), 320-4, 1965 (Japan); C.A. 63, 17089h, 1965.

10. —, - Nishioka, S., and Konishi, K., Yeast production from alcohol distillation slops of cane molasses II, Hakko Kyokaishi 24(10), 457-71, 1966 (Japan); C.A. 64, 20591f, 1966.

11. Official Analytical Methods of the Rum Pilot Plant, 1969. Agri. Exp. Stn, Mayagüez Campus, Univ. P.R.

12. Official Bacteriological Methods of the Rum Pilot Plant, 1969. Agri. Exp. Stn, Mayagüez Campus, Univ. P.R.

13. Rachlevicius, M., Manufacture of dry fodder yeast from slops, Mokslas ir Tech. No. 11, 20-1, 1961; C.A. 57, 3875h, 1962. 
14. Semenets, P.A. and Dokienko, O.I., (Alc. Plant, Andrushevsk, Ukraine), Cultivating fodder yeasts on molasses slops, Spirt. Prom. 29(8), 22-4, 1963; C.A. 60, 9871g, 1964.

15. Skripnik, Y. P., Lerner, I. M., Kongin, A. V., and Baramidze, G. A., Production of feed concentrates which contain protein, antibiotics, and vitamins from refuse from the alcohol industry, Spirtovaya Prom. 27(4), 21-5, 1961; C.A. 55, 20259e, 1961.

16. Standard Methods for Examination of Waste Water. 13th ed, American Public Health Association. New York, 1971.

17. Zabrodskii, A. G., Osovik, A. N., Polyanskaya, E. A., and Ztrizhenyuk, E. V., (Ukr. Nauchao-Issled. Inst. Spirt. Prom. USSR) Possibility of obtaining higher yields of nutrient yeast from molasses residues, Ferment. Spirt. Prom. (1), 40-3, 1973 (Russ); C.A. $78,96056 \mathrm{~g}, 1973$.

18. - Pogrebnaya, V. F., Kravets, E. N., Osovik, A. N., and Bozhik, M. V., Tr. Nauch.Issled Inst. Spirt. Likero-Vodoch, Prom. No. 11, 133-7, 1967 (Russ); C.A. 68, 38156x, 1968. 